Для цитирования: Стукань А.И., Порханов В.А., Бодня В.Н. Клиническая значимость Р16-позитивного статуса и высокой пролиферативной активности у пациентов с орофарингеальной плоскоклеточной карциномой. Сибирский онкологический журнал. 2020; 19(2): 41-48. - doi: 10.21294/1814-4861-2020-19-2-41-48.

For citation: Stukan A.I., Porkhanov V.A., Bodnya V.N. Clinical significance of P16-positive status and high index of proliferative activity in patients with oropharyngeal squamous cell carcinoma. Siberian Journal of Oncology. 2020; 19(2): 41-48. - doi: 10.21294/1814-4861-2020-19-2-41-48.

\title{
CLINICAL SIGNIFICANCE OF P16-POSITIVE STATUS AND HIGH INDEX OF PROLIFERATIVE ACTIVITY IN PATIENTS WITH OROPHARYNGEAL SQUAMOUS CELL CARCINOMA
}

\author{
A.I. Stukan ${ }^{1,3}$, V.A. Porkhanov ${ }^{2,3}$, V.N. Bodnya ${ }^{3}$ \\ Clinical Dispensary of Oncology, Krasnodar, Russia ${ }^{1}$ \\ 146, Dimitrova Street, 350040-Krasnodar, Russia. E-mail: jolie86@bk.ru1 \\ Scientific Investigational Institute State Clinical Hospital № 1 named by professor S.V. Ochapovsky, \\ Krasnodar, Russia ${ }^{2}$ \\ 167, May 1 Street, 350086-Krasnodar, Russia² \\ Kuban State Medical University, Krasnodar, Russia ${ }^{3}$ \\ 4, Mitrofana Sedina Street, 350063-Krasnodar, Russia ${ }^{3}$
}

\begin{abstract}
Introduction. In accordance with UICC and AJCC 8th edition TNM classifications, there is a strong evidence for division of oropharyngeal squamous cell carcinoma (OPSCC) into 2 molecular subtypes by HPV-status with distinct prognosis depending on biological differences. Such a division leads to differences in staging OPSCC and in future it will lead to implementation of preventive measures and new therapeutic strategies against HPV-positive cancer. Aim of the study: to assess the clinical and prognostic significance of the combination of P16, a surrogate marker for HPV-positivity, and high proliferative activity in patients with oropharyngeal carcinoma. Material and Methods. Immunohistochemical (ICH) analysis with monoclonal antibodies specific for P16 and Ki67 proteins was used to detect expression patterns in the formalin-fixed, paraffin-embedded tumor samples obtained from 104 patients with squamous cell carcinoma of the tongue and oropharynx, treated at Oncological Dispencery № 1 in Krasnodar from 2011 to 2016. HPV-positive status was determined if more than $70 \%$ of tumor cells had moderate or strong nuclear and cytoplasmic P16-staining. High index of proliferative activity (PA) was detected if more than $50 \%$ tumor cells expressed Ki67 nuclear antigen. Results. P16-positivie status was associated with tonsillar cancer $(p=0.002)$, female gender $(p=0.015)$, age $\leq 60$ years $(p<0.001)$, non - keratinizing morphology $(p=0.022)$, and high index of PA $(p=0.01)$. The combination of $P 16 \geq 70 \%$ with high PA demonstrated correlation with tonsillar cancer $(p<0.001)$, female gander $(p=0.015)$, age under 60 years $(p<0.001)$ and non - keratinizing morphology $(p=0.012)$. HPVpositive patients and patients with a combination of $\mathrm{P} 16 \geq 70 \%$ and high index of PA at N1-2 had an overall survival benefit ( $p=0.021$ ). Conclusion. The correlation between IHC-complex for $P 16 \geq 70 \% / K i 67>50 \%$ and clinicopathologicl parameters and overall survival confirms the biological features of HPV-associated cancer. The evaluation of this IHC-complex can increase the diagnostic accuracy of IHC-analysis of HPV-status and predict the prognosis of patients with OPSCC.
\end{abstract}

Key words: head and neck cancer, squamous cell carcinoma, human papillomavirus, P16INK4a-expression, Ki67-expression. 


\title{
КЛИНИЧЕСКАЯ ЗНАЧИМОСТЬ Р16-ПОЗИТИВНОГО СТАТУСА И ВЫСОКОЙ ПРОЛИФЕРАТИВНОЙ АКТИВНОСТИ У ПАЦИЕНТОВ С ОРОФАРИНГЕАЛЬНОЙ ПЛОСКОКЛЕТОЧНОЙ КАРЦИНОМОЙ
}

\author{
А.И. Стукань ${ }^{1}$ В.А. Порханов ${ }^{2,3}$, В.Н. Бодня \\ ГБУЗ «Клинический онкологический диспансер №1» Министерства \\ здравоохранения Краснодарского края, г. Краснодар, Россия ${ }^{1}$ \\ Россия, 350040, г. Краснодар, ул. Димитрова, 146. E-mail: jolie86@bk.ru¹ \\ ГБУЗ «Научно-исследовательский институт - Краевая клиническая больница № 1 им. профессора \\ С.В. Очаповского» Министерства здравоохранения Краснодарского края, г. Краснодар, Россия ${ }^{2}$ \\ Россия, 350086, г. Краснодар, ул. 1 Мая, $167^{2}$ \\ ФГБОУ ВО «Кубанский государственный медицинский университет» Министерства \\ здравоохранения Российской Федерации, г. Краснодар, Россия ${ }^{3}$ \\ Россия, 350063, г. Краснодар, ул. Митрофрана Седина, $4^{3}$
}

\section{Аннотация}

\begin{abstract}
Введение. По классификации TNM UICC/AJCC 8-го пересмотра предлагается разделить орофарингеальную плоскоклеточную карциному на 2 молекулярных подтипа по ВПЧ-статусу с различными клиническими и прогностическими характеристиками ввиду биологических особенностей. Так, имеются отличия в подходах к стадированию орофарингеального рака, и в будущем это приведет к реализации профилактических мероприятий и внедрению новых терапевтических стратегий в отношении ВПЧпозитивного рака. Цель исследования - оценить клинико-прогностическую значимость комбинации суррогатного маркера ВПЧ-позитивного статуса Р16 с высокой пролиферативной активностью при орофрарингеальном раке. Материал и методы. Иммуногистохимический анализ выполнен с моноклональными антителами к P16 и Ki67 на срезах с парафиновых гистоблоков опухолевых образцов 104 больных плоскоклеточным раком языка и ротоглотки, проходивших лечение в ГБУЗ КОД № 1 г. Краснодара в 2011-16 гг. Р16-положительный статус определяли при умеренном или сильном ядерном и цитоплазматическом окрашивании более 70 \% опухолевых клеток. Высокий индекс пролиферативной активности устанавливался, если более 50 \% опухолевых клеток имели ядерное окрашивание антигена Ki67. Результаты. Р16-позитивный статус был связан с раком нёбных миндалин ( $p=0,002)$, характерен для женщин $(p=0,015)$, ассоциирован с возрастом моложе 60 лет ( $<<0,001)$, морфологией без ороговения $(p=0,022)$, высокой пролиферацией $(p=0,01)$. Сочетание P16-позитивного статуса с высокой пролиферацией продемонстрировало корреляцию с раком нёбных миндалин $(p<0,001)$, женским полом $(p=0,015)$, возрастом моложе 60 лет ( $<<0,001)$ и морфологией без ороговения $(p=0,012)$. ВПЧ-позитивные больные и пациенты с комбинацией Р16-позитивного статуса и высокого индекса пролиферативной активности с метастазами лимфатических узлов (N1-2) имели более высокие показатели 3-летней общей выживаемости ( $p=0,021)$. Вывод. Корреляция ИГХкомплекса Р16-позитивности и высокой пролиферативной активности с клинико-морфологическими особенностями и общей выживаемостью подтверждает особенности биологии ВПЧ-ассоциированного рака. Исследование комбинации индекса пролиферативной активности в дополнение к суррогатному маркеру ВПЧ-статуса приведет к повышению диагностической точности ИГХ-анализа ВПЧ-статуса и позволит определять прогноз пациентов с плоскоклеточным раком головы и шеи.
\end{abstract}

Ключевые слова: рак головы и шеи, плоскоклеточная карцинома, вирус папилломы человека, P16INK4а-экспрессия, Ki67.

\section{Introduction}

Head and neck squamous cell carcinoma (HNSCC) is the $5^{\text {th }}$ most common malignancy and the $8^{\text {th }}$ leading cause of cancer-related death worldwide [1, 2]. More than 600, 000 new cases of HNSCC are diagnosed annually. In Russian Federation, 5607 cases of pharyngeal cancer were registered in 2018 year. In the Krasnodar region, the South of Russia, 245 cases of pharyngeal cancer were diagnosed in the previous year. The 1-year mortality rates in Russia as a whole and in the Krasnodar region remained dramatically high, being $41.5 \%$ and $45.5 \%$ respectively [3]. Further studies dealing with the development of new treatment strategies and prognostic markers are required.

Tobacco smoking and alcohol consumption are the most important risk factors for HNSCC. In addition, human papillomavirus (HPV) infection plays a causal role in HNSCC $[4,5]$. Oropharyngeal squamous cell carcinoma (OPSCC) is strongly associated with HPV infection. The majority of HPV-related OPSCC cases are caused by HPV16 (50-90\%) [6]. The incidence of oropharyngeal squamous cell carcinoma (OPSCC) 
is increasing in epidemic proportion due to increase in HPV-related squamous cell carcinoma incidence. According to the National Comprehensive Cancer Network (NCCN) guidelines, HPV testing is recommended for all oropharyngeal tumors. Much evidence suggests that HPV-positive and HPV-negative OPSCCs represent distinct subgroups of OPSCC, each with unique epidemiological and biological profiles [7-9].

In some cases, HPV infection can result in the integration of viral DNA into the nuclear DNA of human cells and the expression of oncogenic proteins E6 and E7. This process of integration is a key element of carcinogenesis. E6 protein interacts with tumor growth suppressor protein $\mathrm{p} 53$ and gives a signal to the cell to its destruction. P16 is a tumor growth suppressor that inhibits cyclin-dependent 4A kinase (CDK4a). In the presence of a transcriptionally active HPV virus, the hypophosphorylated retinoblastoma protein binds to the HPV E7 oncoprotein, allowing the E2F transcription activator to be constitutionally active, effectively blocking negative free $\mathrm{pRb}$ feedback on the CDKN2A gene incoding P16. Increased expression of P16 protein occurs as an attempt to hold uncontrolled cell division, which is mediated by a violation of the $\mathrm{pRb}$ pathway. In parallel with HPV detection, immunohistochemical (IHC) determination of P16 expression is often used as a surrogate biomarker for detection of HPV infection and activity of viral oncoproteins, which means the presence of transcriptionally active high oncogenic virus. IHC-staining for P16 detection is mainly an affordable procedure, and the cost of technical research is significantly cheaper than HPVspecific tests. In accordance with UICC and AJCC 8th edition TNM classifications, it is recommended to use a separate staging system for P16-positive OPSCC [10, 11]. The Guidelines from the College of American Pathologists recommend that pathologists should perform high-risk HPV testing on all patients with newly diagnosed OPSCC using surrogate marker P16 IHC. Additional HPV-specific testing may be done at the discretion of the pathologist and/or oncologist or in the context of a clinical trial. Expression of P16 $\geq 70 \%$ of tumor cells with moderate and strong nuclear and/ or cytoplasmic staining can be considered a surrogate marker of HPV-positive tumor [12, 13].

The prognostic value of Ki67 antigen expression in head and neck cancer is being actively studied. Ki67 is detected by immunohistochemical method in the presence of nuclear staining. It is detected in the phases G1, S, G2 and mitosis M of cell cycle, and its absence was noted in the stage G0. The Ki67 index is calculated as the number of stained cells per 1000 tumor cells, and it is directly proportional to the number of actively dividing cells in normal tissues and correlates with mitotic activity. Due to the established prognostic role of the Ki67 antigen in HNSCC, these studies indicate that this molecular marker can be used for stratification of patients without metastatic lesions of regional lymph nodes as prognostically favorable. The Ki67 IHC staining level of less than $10 \%$ of tumor cells suggests a favorable prognosis, and Ki67>10\% indicates an unfavorable prognosis [14].

The aim of the study was to evaluate the clinical significance of the combination of IHC markers of P16-positivity and high proliferation of Ki67 in patients with OPSCC.

\section{Material and Methods \\ Object of study and design}

We investigated medical records and formalinfixed, paraffin-embedded tumor samples from 104 patients with squamous cell oropharyngeal carcinoma and squamous cell carcinoma of the tongue (table 1). The patients were treated at Clinical Oncological Dispencery № 1of Krasnodar region, from 2011 to 2016. The follow-up period ranged from 6 to 72 months.

\section{Immunohistochemical analysis}

Pretreatment tumor specimens were obtained and immunohistochemistry was performed on paraffin sections by the automated method on immunohistostainer ThermoScentific using monoclonal antibodies specific for P16 (INK4 BioGenex clone at a dilution of 1:25) and Ki67 (clone SP6, LabVision at a dilution of 1:400). The reaction was visualized by the UltraVisionQantoDetectionSystem HRP DAB (ThermoScentific) detection system. HPV-status was considered positive when more than $70 \%$ of tumor cells inclusive had moderate and strong nuclear and cytoplasmic P16-staining. IHC staining of Ki67 less $25 \%$ of tumor cells was characterized as a low degree of expression, the interval $25-50 \%$ was considered as moderate proliferation and a high index of proliferation activity was established if more than $50 \%$ of tumor cells expressed Ki67 antigen.

\section{Statistical analysis}

The statistical analysis was performed using the statistical package IBM SPSS statistics version 22. Under the normal distribution of the trait in accordance with the Kolmogorov-Smirnov test, the Student's t-test for independent samples was used in the comparative analysis of the mean values. Otherwise, the method of nonparametric analysis (Mann-Whitney U-test) was used. To assess the reliability of differences in the clinical and histopathological features in subgroups of HPV- status was used the method of distribution according to Pearson $\chi^{2}$, in the cases provided by statistical methods, the index was calculated with Yates' correction. The value of $p<0.05$ was estimated as statistically significant. The relative risk of detecting HPV-positivity was assessed depending on individual clinical and morphological parameters with the calculation of $95 \%$ CI. To assess overall survival depending on risk factors, the Kaplan-Meier curves were used, significance of differences was determined by log-rank test. The value of $p<0.05$ was estimated as statistically significant. 
Таблица 1/Table 1

\section{Клинические и патологические характеристики} пациентов

\section{Clinical and pathologic characteristics of patients}

\begin{tabular}{cc}
\hline Параметры/Parameter & $\begin{array}{c}\text { Количество больных/ } \\
\text { Number of patients }\end{array}$ \\
\hline Возраст/Age & $59(56.7 \%)$ \\
$\leq 60$ лет/years & $45(43.3 \%)$ \\
$>60$ лет/years & $87(84 \%)$ \\
Пол/Gender & $17(16 \%)$ \\
Мужской/Male & \\
Женский/Female & $23(22 \%)$ \\
Локализация/Localization & $29(28 \%)$ \\
Основание языка/ & $31(30 \%)$ \\
Ваsе of the tongue & $8(8 \%)$ \\
Стенки гортани, гортаноглотки/ \\
Lатеral рharyngeal walls \\
Миндалины/Palatine tonsils \\
Мягкое небо/Soft palatine \\
Основание языка/ \\
Воду of the tongue
\end{tabular}

Патологические особенности/Pathologic features

$\begin{array}{ll}\text { G1 } & 19(18 \%) \\ \text { G2 } & 60(58 \%) \\ \text { G3 } & 25(24 \%) \\ \text { овевающий/ } & 38(40 \%) \\ \text { keratizing } & \end{array}$

$$
\text { Non-keratizing }
$$

Ороговевающий/Keratizing $62(60 \%)$

TNM ( $7^{\text {th }}$ edition $)$

$\begin{array}{cc}\text { T1 } & 7(6 \%) \\ \text { T2 } & 26(25 \%) \\ \text { T3 } & 37(36 \%) \\ \text { T4a } & 34(33 \%) \\ \text { N0 } & 60(57.7 \%) \\ \text { N1-2 } & 44(52.3 \%)\end{array}$

\section{Results}

\section{P16-expression}

A total of 104 patients were diagnosed with HPVpositive OPSCC. According to HPV status, patients were divided into two groups. The first group consisted of 79 patients with HPV-negative status. The second group included $25 \mathrm{HPV}$-positive patients with P16-positive status. There were significantly more men than women in both groups (88.6 and $68 \%$ respectively), but the proportion of female gender was significantly higher in HPV-positive group $(\mathrm{RR}=2.8$, $95 \% \mathrm{CI}=1,213-6,503, \mathrm{p}=0,015)$. As for age, in the first group there were $54.4 \%$ (43 of 79) of patients older than 60 years. $22(88 \%)$ HPV-positive patients were significantly younger than 60 years $(\mathrm{RR}=1.9,95 \%$ $\mathrm{CI}=1.458-2.558, \mathrm{p}<0.001)$.
It was revealed that cancer of the base of the tongue was associated with $\mathrm{P} 16$-positive status $(\mathrm{RR}=2.431$, $95 \% \mathrm{CI}=1.218-4.851 \mathrm{p}=0.014)$. Tonsillar cancer also demonstrated P16-positivity $(\mathrm{RR}=2.602,95 \%$ $\mathrm{CI}=1.507-4.492, \mathrm{p}=0.002)$. Cancer of the lateral walls of the oropharynx had an inverse correlation with P16positivity $(\mathrm{RR}=0.113,95 \% \mathrm{CI}=0.016-0.788, \mathrm{p}<0.05)$, and was observed in $35.4 \%$ (28 out of 79) cases with P16-negative tumors and in $40 \%$ (10 out of 25) of P16-positive tumors. The risk of P16-positive status for the non-keratinizing type of HNSCC increased by more than 1.5 times $(\mathrm{p}<0.05, \mathrm{RR}=1.756,95 \%$ $\mathrm{CI}=1.127-2.734$ ). There was no statistically significant association between HPV-status and the size (T) of the primary tumor $(\mathrm{p}=1.000)$. A direct significant correlation with HPV-positive status was revealed at $\mathrm{N} 1-2$ OPSCC $(\mathrm{p}=0.022)$.

\section{Ki6 7 proliferative activity $(P A)$}

The expression of Ki67 was determined by the percentage of positive tumor cells. The mean value was $52.15 \pm 2.674 \%(95 \% \mathrm{CI}=46.85-57.46)$, the median was $55 \%$ with interquartile range $25-80$. When assessing the proliferative potential of the cells in the studied groups, the presence of low (0-20\%), moderate (21-50\%) and high PA (51-100 \%) was revealed. Of all patients, 55 (53\%) had high Ki67 expression and 37 (35.5\%) had moderate Ki67 expression. Patients were divided into 2 groups according to the index of PA. In the first group patients, Ki67 was expressed in less than $50 \%$ of tumor cells. In the second group patients, Ki67 was expressed in more than $50 \%$ of cancer cells. The Ki67 expression of more than $50 \%$ was associated with female gender $(\mathrm{RR}=3.009,95 \% \mathrm{CI}=1.050-8.622, \mathrm{p}=0.027)$ and age $\leq 60$ years $(\mathrm{RR}=1.6,95 \% \mathrm{CI}=1.701-4.122, \mathrm{p}=0.007)$. It was found that the mean value of Ki67 expression was $72.28 \pm 4.193 \%(95 \% \mathrm{CI}=63.63-80.93)$, the median was $80 \%$ for P16-positivity. In the case of P16-negative status, the mean value was $45.78 \pm$ $2.924 \%(95 \% \mathrm{CI}=39.96-51.61)$, the median was $40 \%$. Comparison of the means of marker using the Mann-Whitney U-test indicated statistically significant differences in the groups and higher proliferation index in the group of P16-positive patients. High index of PA was observed in cancer of the base of the tongue $(\mathrm{RR}=2.116,(95 \% \mathrm{CI}=0.950-4.713, \mathrm{p}=0.056)$. The inverse relationship between the cancer of the body of the tongue and the high index of PA ( $R R=0.278$, $95 \% \mathrm{CI}=0.081-0.952, \mathrm{p}=0.027$ ) was statistically significant. Other cancer sites, such as tonsils, lateral oropharyngeal walls and soft palate did not demonstrate association with Ki67 expression $(p=0.414$, $p=0.664, p=0.396$, respectively). High index of PA was inversely associated with high grade of differentiation G1 $(\mathrm{RR}=0.331,95 \% \mathrm{CI}=0.128-0.852, \mathrm{p}=0.024)$. In the presence of high PA, the feasibility of G2 detection was increased $(\mathrm{RR}=1.49,95 \% \mathrm{CI}=1.128-2.812$, $\mathrm{p}=0.024)$. The relationship between the high index of PA and the non-keratinizing morphology was also ob- 
served $(\mathrm{RR}=1.667,95 \% \mathrm{CI}=1.148-3.152, \mathrm{p}=0.038)$.

Correlation of combination of expression of $P 16 \geq 70 \%$ and Ki67>50 \% with clinical and morphological parameters

According to the revealed statistically significant association of HPV-positive status with high index of PA, and their independent correlations with sex, age, localization and morphology of HNSCC, it was advisably to evaluate the diagnostic value of combination of P16-positive status and high level of PA (P16 $\geq 70 \%$ and $\mathrm{Ki} 67>50 \%$ ) as a IHC-complex reflecting the biology of cancer and determining the clinicopathological features of the tumor (table 2).

Prognostic role of IHC-complex (P16 $\geq 70 \%$ and Ki67>50\%) in overall survival (OS)

Of the 104 patients, 66 were followed up from 2011 to 2014 with the median follow-up time of 36 months. Of these 66 patients, $41(62 \%)$ were $\leq 60$ years and $25(38 \%)$ were older than 60 years. The mean age of the patients was $57.39 \pm 1.176$ years (95\% CI=55.04-59.74). There were 18 (27\%) patients with cancer of the base of the tongue, 21 (32\%) with cancer of palatine tonsils, $7(11 \%)$, with cancer of soft palate, $15(22 \%)$ with cancer of lateral walls of the oropharynx, and $5(8 \%)$ with tongue cancer. Patients were distributed into N0 neck group (40 patients) and into N1-2 neck group (26 patients). Only 25 (40\%) patients had T1-2 primary tumor and 41 patients had T 3-4. Stages I-II were detected in $12(18 \%)$ and IIIIV - in $54(82 \%)$ cases. Depending on the stage of the disease, patients received surgical treatment followed by radiation therapy, chemotherapy followed by RT, RT alone, chemotherapy, concurrent chemoradiation in $3 \%, 27 \%, 30 \%, 1.5 \%$ of cases, respectively.

In the examined cohort of patients, the 3-year OS rate was $51.5 \%$. OS was assessed by P16-status. The first group consisted of $68 \%$ (45 out of 66) HPVnegative patients, and the second $-32 \%$ (21 out of 66 ) HPV-positive patients. The mean age of the patients with P16-negative status was $59.07 \pm 1.460$ years (95\% CI=56.12-62.01). The median was 59 years. The mean age of P16-positive patients was 53.81 \pm 1.772 years $(95 \% \mathrm{CI}=50.11-57.01)$. The median was 55 years. OS in P16-negative group was 35.161 \pm 4.550 months. The median was $20 \pm 6.707$ months. OS for HPV-positive patients was $53.836 \pm 4.819$ months. Difference in OS depending on P16-status was assessed by log rank test. The 3 -year OS rate was

Таблица 2/Table 2

\section{Корреляция комбинации Р16-позитивности и высокого РА (P16 $\geq 70$ \% и Ki67>50 \%) с демографическими и клинико-патологическими параметрами}

\section{Correlation of combination of P16-positivity and high PA (P16 $\geq 70 \%$ and Ki67>50 \%) with demographics and clinicopathological parameters}

\begin{tabular}{|c|c|c|c|c|}
\hline \multirow[b]{2}{*}{$\begin{array}{l}\text { Параметры/ } \\
\text { Parameters }\end{array}$} & \multicolumn{2}{|c|}{ IHC-complex (P16 $\geq 70 \%$ and Ki67>50\%) } & \multirow{2}{*}{$\begin{array}{c}\text { Относительный риск/ } \\
\text { RR (relative risk) 95\% } \\
\text { CI }\end{array}$} & \multirow{2}{*}{$\begin{array}{l}\text { Значимость (p)/ } \\
\text { Significance (p) }\end{array}$} \\
\hline & $\begin{array}{c}\text { Присутствует/ } \\
\text { Present }\end{array}$ & $\begin{array}{l}\text { Отсутствует/ } \\
\text { Absent }\end{array}$ & & \\
\hline Женщины/Female & $8(35 \%)$ & $9(11 \%)$ & \multirow{2}{*}{$3.130(1.362-7.195)$} & \multirow{2}{*}{$0.017^{*}$} \\
\hline Мужчины/Male & $15(65 \%)$ & $72(89 \%)$ & & \\
\hline Age/Возраст, $\leq 60$ & $20(87 \%)$ & $38(47 \%)$ & \multirow{2}{*}{$1.854(1.400-2.454)$} & \multirow{2}{*}{$0.002 *$} \\
\hline Age/Возраст, $>60$ & $3(13 \%)$ & $43(53 \%)$ & & \\
\hline Основание языка/Base of the tongue & $8(34.7 \%)$ & $15(18.5 \%)$ & $1.878(0.912-3.868)$ & 0.170 \\
\hline Основание языка/Body of the tongue & 0 & $13(16 \%)$ & $0.000(0.000-\mathrm{NaN})$ & $>0.05$ \\
\hline Миндалины/Palatine tonsils & $14(61 \%)$ & $17(21 \%)$ & $2.900(1.699-4.951)$ & $<0.001^{*}$ \\
\hline $\begin{array}{c}\text { Латеральные ротоглоточные стенки/ } \\
\text { Lateral oropharingeal walls }\end{array}$ & $1(4.3 \%)$ & $28(34.5 \%)$ & $0.990(0.018-0.875)$ & $<0.05^{*}$ \\
\hline Мягкое небо/Soft palatine & 0 & $8(10 \%)$ & $1.878(0.912-3.868)$ & $>0.05$ \\
\hline G1 & $3(13 \%)$ & $16(20 \%)$ & $0.660(0.211-2.071)$ & $>0.05$ \\
\hline $\mathrm{G} 2$ & $14(61 \%)$ & $46(56.6 \%)$ & $1.072(0.734-1.565)$ & 0.913 \\
\hline G3 & $6(26 \%)$ & $19(23.4 \%)$ & $1.112(0.503-2.457)$ & 0.988 \\
\hline Неороговевающий/Non-keratinizing & $15(65 \%)$ & $27(33.3 \%)$ & \multirow{2}{*}{$1.957(1.274-3.004)$} & \multirow{2}{*}{$0.012 *$} \\
\hline Ороговевающий/Keratizing & $8(35 \%)$ & $54(66.7 \%)$ & & \\
\hline $\mathrm{T} 1-2$ & $6(26 \%)$ & $27(33.3 \%)$ & \multirow{2}{*}{$0.783(0.368-1.663)$} & \multirow{2}{*}{0.685} \\
\hline $\mathrm{T} 3-4$ & $17(74 \%)$ & $54(66.7 \%)$ & & \\
\hline No & $7(30 \%)$ & $53(65.4 \%)$ & \multirow{2}{*}{$2.012(1.344-3.013)$} & \multirow{2}{*}{$0.006^{*}$} \\
\hline N1-2 & $16(70 \%)$ & $28(34.6 \%)$ & & \\
\hline
\end{tabular}

Примечание: * статистическая значимость, $\mathrm{p}<0,05$

Notes: * statistical significance, $\mathrm{p}<0.05$ 


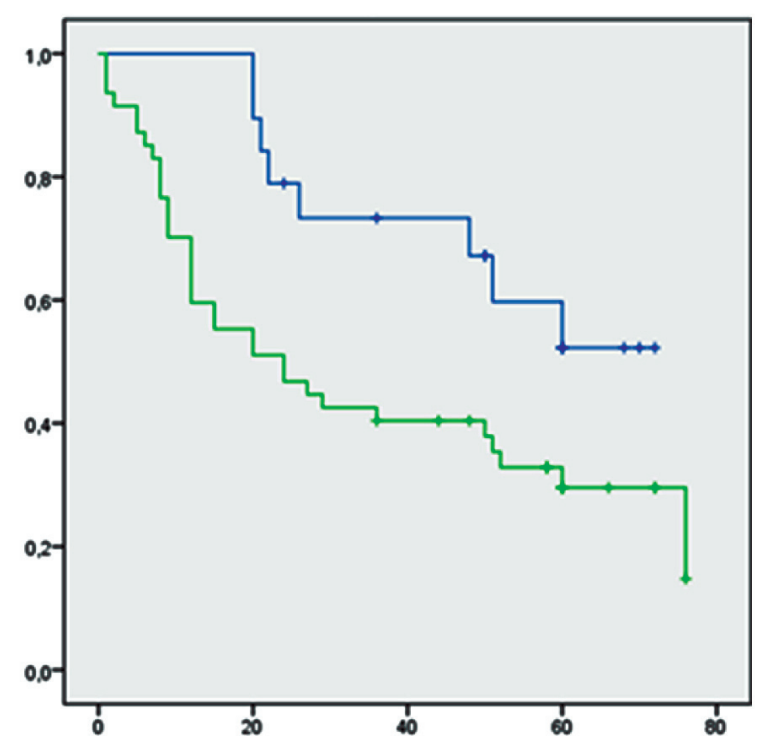

Рис. 1. Показатели выживаемости по методу КапланаМайера в зависимости от наличия или отсутствия комбинации IHC P16 $\geq 70 \%$ и Кi67>50\%

Fig.1. Kaplan-Mayer survival curves by the presence or absence of IHC-combination P16 $\geq 70 \%$ and Ki67>50 \%

$71.4 \%$ for HPV-positive patients and $42.2 \%$ for P16negative patients. A statistically significant advantage in OS for P16-positive patients was revealed $\left(\chi^{2}=5.325\right.$ $\mathrm{p}=0.021, \log$ rank test).

To identify the dependence of OS on the IHC-combination of P16-positivity with high proliferative activity, patients were divided into 2 groups. The first group included patients with the presence of IHC-complex of markers. In the second group, it was absent. The mean life expectancy was $54.686 \pm 5.005$ months for the first group and $35.728 \pm 4.435$ months for the second group. Kaplan-Mayer survival curves were constructed (fig. 1). The overall survival difference depending on the IHC-complex P16 $\geq 70 \%$ and Ki67 $>50 \%$ was estimated by the log rank test. A statistically significant advantage in OS for patients with the presence of IHCcombination of $\mathrm{P} 16$-positivity with high proliferative activity was revealed $\left(\chi^{2}=5.041, \mathrm{p}=0.025\right)$.

These groups of patients were also analyzed in terms of OS, depending on the regional lymph node metastatic involvement $(\mathrm{T})$. The median of OS was 51 month (25-60). In the case of N1-2, the median of OS was 24 months (12-24). In cases with N1-2, the median was 9 (2-76). The Kaplan-Mayer survival curves are constructed to estimate the differences in OS (fig. 2, 3). The OS rate depending on the IHC-complex $\mathrm{P} 16 \geq 70 \%$ and $\mathrm{Ki} 67>50 \%$ was estimated by log rank test. Differences in overall survival by N0-status were not statistically significant $\left(\chi^{2}=0.381, \mathrm{p}=0.537\right)$. A significant advantage in OS by the presence IHC-complex $\mathrm{P} 16 \geq 70 \%$ and $\mathrm{Ki}-67>50 \%$ for N1-2 patients was revealed $\left(\chi^{2}=1.137, \mathrm{p}=0.021\right)$.

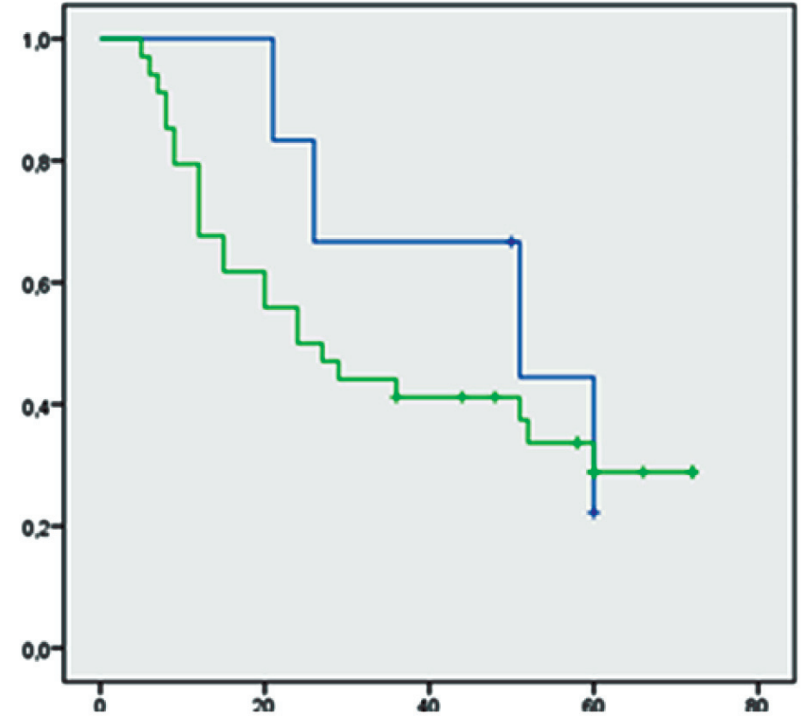

Рис. 2. Показатели выживаемости по методу КапланаМайера в зависимости от наличия или отсутствия IHCкомплекса P16 $\geq 70$ \% и Ki67 >50 \% при N0

Fig. 2. Kaplan-Mayer survival curves by the presence or absenceof IHC-complex P16 $270 \%$ and Ki67>50 \% at N0

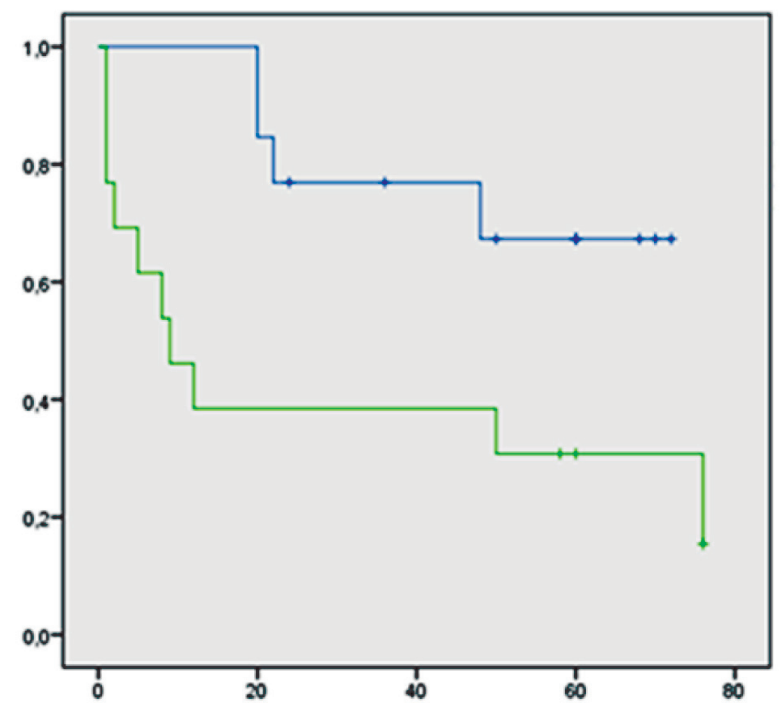

Рис. 3. Показатели выживаемости по методу КапланаМайера в зависимости от наличия или отсутствия IHCкомплекса P16 $\geq 70$ \% и Кi67>50 \% при N1-2

Fig. 3. Kaplan-Mayer survival curves by the presence or absence of IHC-complex P16 $\geq 70 \%$ and Ki67 $>50 \%$ at N1-2

\section{Conclusion}

The data indicate a significant role of viral carcinogenesis in the studied group of patients with OPSCC in the South of Russia. The incidence of P16INK4A surrogate marker of HPV-positive status in the examined cohort of patients was $24 \%$. In this regard, there are new opportunities for the prevention of head and neck cancer through the introduction of preventive measures against the human papillomavirus-infection of high oncogenic risk and vaccination of the population. The prevalence of women among patients with HPV-positive oropharyngeal cancer is not consistent 
with the global data, where this group of patients mainly consists of young men. With regard to the age of patients with HPV-positive cancer, the study group confirmed the global trend towards a younger age of manifestation of the disease. Basically, tonsillar carcinoma and cancer of the base of the tongue demonstrate HPV-positive status. It seems appropriate to identify the features of local immunity in cancer of these localizations. Pathogenetic parameters such as non-keratinizing morphological type of tumor cells and a high proliferative activity also characterize HPV-positive cancer according to our data and the results of published studies in literature. Taking into account the statistically significant direct relationship between HPV status and high proliferative activity, an opinion about the specific biology of HPV-positive tumor was formed. In connection with the association of HPVstatus and Ki67 with the sex, age, localization and morphology of squamous cell carcinoma of the head and neck, it has seemed expedient to estimate the information content of the identification combination of expression of $\mathrm{P} 16 \geq 70 \%$ and $\mathrm{Ki} 67>50 \%$ in tumors of patients with HNSCC. It was found that the presence of an IHC-complex of these markers significantly correlated with the female sex, age $\leq 60$ years, localization in the tonsils, non-keratinizing morphology and increased risk of locoregional metastatic potential.

\section{ЛИТЕРАТУРА/REFERENCES}

1. The Cancer Genome Atlas Network. Comprehensive genomic characterization of head and neck squamous cell carcinomas. Nature. 2015 Jan 29; 517(7536): 576-82. doi: 10.1038/nature14129.

2. Galloway D.A., Laimins L.A. Human papillomaviruses: shared and distinct pathways for pathogenesis. Curr Opin Virol. 2015 Oct; 14: 87-92. doi: 10.1016/j.coviro.2015.09.001.

3. Каприн А.Д., Старинский В.В., Петрова Г.В. Состояние онкологической помощи в России в 2018 году. М., 2019. 250 с. [Kaprin A.D., Starinckiy V.V., Petrova G.V. The state of cancer care in Russia in 2018. Moscow; 2019. 250 p. (in Russian)].

4. Jiron J., Sethi S., Ali-Fehmi R., Franceschi S., Struijk L., van Doorn L.J., Quint W., Kato I. Racial disparities in Human Papillomavirus(HPV) associated head and neck cancer. Am J Otolaryngol. 2014 Mar-Apr; 35(2): 147-53. doi: 10.1016/j.amjoto.2013.09.004.

5. Черемисина О.В., Чойнзонов Е.Л., Панкова О.В., Мухамедов М.Р., Уразова Л.Н., Дворянинова О.Ю. Папилломатоз как критерий формирования группы риска по раку гортани. Вестник оториноларингологии. 2015; 80(1): 39-43. [Cheremisina O.V., Choinzonov E.L. Pankova O.V., Mukhamedov M.R., Urazova L.N., Dvorianinova O.Yu. Papillomatosis as a criteria for the formation of the group at risk of laryngeal cancer. Bulletin Otorinolaringology. 2015; 80(1): 39-43. (in Russian)].

6. Gronhoj L.C., Gyldenlove M., Jensen D.H., Therkildsen M.H., Kiss K., Norrild B., Konge L., von Buchwald C. Correlation between human papillomavirus and P16 overexpression in oropharyngeal tumours: a systematic review. Br J Cancer. 2014 Mar 18; 110(6): 1587-94. doi: 10.1038/bjc. 2014.42 .

7. Galloway D.A., Laimins L.A. Human papillomaviruses: shared and distinct pathways for pathogenesis. Curr Opin Virol. 2015 Oct; 14: 87-92. doi: 10.1016/j.coviro.2015.09.001.
The statistically significant advantage of the OS in the group of patients with the presence of IHC-complex also confirms the peculiarities of HPV-positive tumor behavior. Taking into account this parameter, it may be feasible to increase the specificity and diagnostic accuracy of the method for determining HPV status by IHC analysis of the surrogate marker P16 including Ki67 expression detection.

\section{Discussion}

Simultaneous detection of P16 and determination of proliferative activity index in tumor epithelial cells can be interpreted as a surrogate marker of cell cycle regulation disorders in high oncogenic risk HPV infection. Proliferative activity is proposed to be a good prognostic marker of response to chemo- and radiotherapy due to established biological explanation of high sensitivity of actively proliferating tumors. Higher overall survival rates in HPV-positive OPSCC identify opportunities for de-intensification of treatment regimens to reduce the toxic effects of therapy. There is also strong evidence for the appropriate introduction of the combined IHC-analysis of P16 expression with Ki67 expression into clinical oncology practice as the diagnostic tool to determine the prognosis of patients with OPSCC.

8. Wang Z., Xia R.H., Ye D.X., Li J. Human Papillomavirus 16 Infection and TP53 Mutation: Two Distinct Pathogeneses for Oropharyngeal Squamous Cell Carcinoma in an Eastern Chinese Population. PLoS One. 2016 Oct 17; 11(10): e0164491. doi: 10.1371/journal.pone.0164491.

9. Johnson M.E., Cantalupo P.G., Pipas J.M. Identification of head and neck cancer subtypes based on human papillomavirus presence and E2Fregulated gene expression. mSphere. 2018 Jan 10; 3(1). pii: e00580-17. doi: 10.1128/mSphere.00580-17.

10. Huang S.H., O'Sullivan B. Overview of the 8th Edition TNM Classification for Head and Neck Cancer. Curr Treat Options Oncol. 2017 Jul; 18(7): 40. doi: 10.1007/s11864-017-0484-y.

11. Prigge E.S., Arbyn M., von Knebel Doeberitz M., Reuschenbach M. Diagnostic accuracy of P16INK4a immunohistochemistry in oropharyngeal squamous cell carcinomas: a systematic review and meta-analysis. Int J Cancer. 2017 Mar 1; 140(5): 1186-98. doi: 10.1002/ijc.30516.

12. Lewis J.S.Jr. P16 Immunohistochemistry as a standalone test for risk stratification in oropharyngeal squamous cell carcinoma. Head Neck Pathol. 2012 Jul; 6 Suppl 1: S75-82. doi: 10.1007/s12105-012-0369-0.

13. Lewis J.S.Jr., Beadle B., Bishop J.A., Chernock R.D., Colasacco C. Lacchetti C., Moncur J.T., Rocco J.W., Schwartz M.R., Seethala R.R., Thomas N.E., Westra W.H., Faquin W.C. Human Papillomavirus Testing in Head and Neck Carcinomas: Guideline From the College of American Pathologists. Arch Pathol Lab Med. 2018 May; 142(5): 559-97. doi: 10.5858/arpa.2017-0286-CP.

14. Mielcarek-Kuchta D., Olofsson J., Golusinski W. p53, Ki67 and cyclin D1 as prognostic factors of lymph node metastases in laryngeal carcinoma. Eur Arch Otorhinolaryngol. 2003; 260(10): 549-54. doi: 10.1007/ s00405-003-0651-6.

Поступила/Received 05.03.2019 Принята в печать/Accepted 13.06.2019

\section{СВЕДЕНИЯ ОБ АВТОРАХ}

Стукань Анастасия Игоревна, врач-онколог, ГБУЗ «Клинический онкологический диспансер № 1» (г. Краснодар, Россия). SPIN-код: 9155-6715. AuthorID (РИНЦ): 1025660. Researcher ID (WOS): E-5524-2019. ORCID: 0000-0002-0698-7710. E-mail: jolie86@bk.ru.

Порханов Владимир Алексеевич, доктор медицинских наук, профессор, академик РАН, главный врач ГБУЗ «НИИ - Краснодарская краевая больница № 1»; заведующий кафедрой онкологии с курсом торакальной хирургии, ФГБУ ВПО «Кубанский государственный медицинский университет» (г. Краснодар, Россия). SPIN-код: 2446-5933. AuthorID (PИНЦ): 682896. Researcher ID (WOS): O-9470-2017. ORCID: 0000-0003-0572-1395. 
Бодня Вадим Николаевич, доктор медицинских наук, доцент кафедры онкологии с курсом торакальной хирургии, ФГБУ ВПО «Кубанский государственный медицинский университет» (г. Краснодар, Россия). SPIN-код: 8506-1987. AuthorID (PИНЦ): 740756. Researcher ID (WOS): F-2670-2019. ORCID: 0000-0003-3169-9558.

\section{ВКЛАД АВТОРОВ}

Стукань Анастасия Игоревна: разработка концепции научной работы, статистическая обработка, составление черновика рукописи.

Порханов Владимир Алексеевич: анализ научной работы, критический пересмотр с внесением ценного интеллектуального содержания.

Бодня Вадим Николаевич: анализ литературы по теме статьи, правка черновика рукописи, критический пересмотр с внесением ценного интеллектуального содержания.

\section{Финансирование}

Это исследование не потребовало дополнительного финансирования. Конфликт интересов

Авторы объявляют, что у них нет конфликта интересов.

\section{ABOUT THE AUTHORS}

Anastasia I. Stukan, oncologist, Clinical Dispensary of Oncology (Krasnodar, Russia). Researcher ID (WOS): E-5524-2019. ORCID: 0000-0002-0698-7710. E-mail: jolie86@bk.ru.

Vladimir A. Porkhanov, DSc, Professor, Academician RAS, Head of Scientific Investigational Institute State Clinical Hospital № 1 named by professor S.V. Ochapovsky; Head of Department of Oncology with Course of Thoracic Surgery of Kuban State Medical University (Krasnodar, Russia). Researcher ID (WOS): O-9470-2017. ORCID: 0000-0003-0572-1395.

Vadim N. Bodnya, DSc, Department of Oncology with Course of Thoracic Surgery of Kuban State Medical University (Krasnodar, Russia). Researcher ID (WOS): F-2670-2019. ORCID: 0000-0003-3169-9558.

\section{AUTHOR CONTRIBUTION}

Anastasia I. Stukan: study conception, statistical data analysis, drafting of the manuscript.

Vladimir A. Porkhanov: analysis of the study results, critical revision for the important intelectual content.

Vadim N. Bodnya: data collection, drafting of the manuscript, critical revision for the important intelectual content.

\section{Funding}

This study required no funding.

Conflict of interest

The authors declare that they have no conflict of interest. 